\author{
Jerzy Parchomiuk ${ }^{*}$
}

\title{
KONFLIKT DÓBR I WARTOŚCI CHRONIONYCH W PRAWIE ADMINISTRACYJNYM NA PRZYKLADZIE NADUŻYCIA WLADZTWA PLANISTYCZNEGO GMINY
}

\section{Uwagi wstępne}

Aktywność administracji publicznej, nastawiona na zaspokajanie zbiorowych potrzeb jednostek żyjących w społecznościach immanentnie niesie ze sobą ryzyko kolizji dóbr i wartości prawnie chronionych. Dążenie do realizacji interesu publicznego z reguły oznacza ingerencję i ograniczenie wolności jednostki. Mogą również pojawiać się konflikty pomiędzy sferami dóbr prawnie chronionych różnych jednostek, jak również problem konkurencji różnych dóbr (wartości), ważnych z punktu widzenia tej samej kategorii interesu. Planowanie przestrzenne ze swojej natury należy do dziedzin szczególnie konfliktogennych, realizacja jego podstawowych determinant - ładu przestrzennego i zrównoważonego rozwoju, wielokrotnie oznacza ingerencję w materialny fundament wolności jednostki - w prawo własności. Polaryzacja interesu publicznego i indywidualnego jest w tym obszarze szczególnie widoczna.

Do klasyki można już zaliczyć wypowiedź judykatury, że w demokratycznym państwie prawnym nie istnieje sztywno pojmowany prymat interesu publicznego nad prywatnym ${ }^{1}$. Rolą organów administracyjnych jest poszukiwanie takiej drogi realizacji interesu publicznego, która nie zniweczy wolności jednostki, zaś prawo administracyjne powinno być instrumentem ważenia kolidujących wartości, a proporcjonalność kluczową determinantą ingerencji w sferę prawną jednostki.

Konflikt wartości to problem, który może być analizowany z rozmaitych punktów widzenia: przede wszystkim filozoficznego (w tym etycznego), ale także: socjologicznego, politologicznego, psychologicznego i prawnego. Analiza zagadnienia $\mathrm{w}$ aspekcie prawnym, nawet zawężonym do sfery prawa administracyjnego wymagałaby szerokiego, monograficznego opracowania. Będąc ograniczony

\footnotetext{
* Dr, Instytut Prawa Katedra Prawa Administracyjnego, Wydział Prawa, Prawa Kanonicznego i Administracji Katolickiego Uniwersytetu Jana Pawła II.

1 Wyrok SN z 18 listopada 1993 r. (III ARN 49/93; OSNCP 1994, nr 9, poz. 181).
} 
ramami artykułu mogę jedynie zwrócić uwagę na pewne podstawowe cechy tego zjawiska $\mathrm{w}$ takim zakresie, $\mathrm{w}$ jakim będzie to konieczne dla przedstawienia studium przypadku, w którym jak w soczewce skupiają się zasadnicze problemy konfliktu dóbr i wartości w prawie administracyjnym - zjawiska nadużycia władztwa planistycznego. Koncepcja „nadużycia” władczych kompetencji jest tu stosowana jako instrument limitowania pewnej sfery luzu decyzyjnego administracji, pewnego obszaru swobody, który musi być ograniczany, jednak precyzyjne wyrażenie (opisanie) tych granic normami prawnymi nie jest możliwe z uwagi na wieloaspektowość możliwych stanów faktycznych.

\section{Konflikt dóbr i wartości chronionych a konflikt interesów w prawie administracyjnym}

Wielowymiarowość pojęcia wartości utrudnia przyjęcie pewnych założeń terminologicznych dla dalszej analizy, zwłaszcza przy ograniczonych wymogami edytorskimi artykułu ramach wypowiedzi. Skoro chodzi o pojęcie wartości chronionych prawem celowe wydaje się na wstępie odwołanie do filozoficznego sporu pojęciowego pomiędzy kierunkami kognitywizmu i a(anty-)kognitywizmu. Pierwszy zakłada ontologię wartości - wartości w jakiś sposób istnieją i są poznawalne (intuicyjnie lub poprzez stwierdzanie określanych właściwości naturalnych). Drugi odrzuca bytowość wartości, a w konsekwencji możliwość ich poznania, sprowadzając je do refleksów czyichś ocen. W tym ujęciu pojęcie wartości jest określeniem cechy przedmiotów przez kogoś dodatnio lub ujemnie ocenianych $^{3}$.

Nawet jednak autorzy przyjmujący postawę akognitywistyczną dostrzegają, że prawo obowiązujące wyraża w swoich normach zespoły wartości, które stanowią aksjologiczne uzasadnienie ustanawianych norm prawnych i które podlegają rekonstrukcji w procesach analizy tekstów prawa. Są to tzw. wartości wewnętrzne prawa. $\mathrm{Z}$ drugiej strony wskazuje się na istnienie wartości zewnętrznych prawa, rozumianych jako rezultaty oceny prawa obowiązującego z punktu widzenia jakichś pozaprawnych kryteriów ${ }^{4}$. Odrzucenie założenia ontologii wartości prowadzi jednak do pytania, czym są owe pozaprawne kryteria, w oparciu o które dokonuje się zewnętrzne wartościowanie prawa.

Ponadto odwołanie się tylko do wartości wewnętrznych prawa stwarza niebezpieczeństwo ich instrumentalizacji przez podmioty sprawujące realną władzę i stanowiące prawo. Może temu przeciwdziałać hierarchizacja wartości wewnętrz-

2 Zob. szerzej Z. Ziembiński, Wstęp do aksjologii dla prawników, Warszawa 1990, s. 57-60.

3 Por. Z. Ziembiński, Wartości konstytucyjne, Warszawa 1993, s. 12 i 15; tenże, Wstęp do aksjologii..., s. 58.

4 J. Wróblewski, Wartość a decyzja sądowa, Wrocław 1973, s. 47-48. 
nych prawa poprzez wyrażenie kluczowych, fundamentalnych z nich w normach stanowiących fundament hierarchicznej struktury systemu prawa (konstytucji).

Trzeba założyć, że ustawa zasadnicza wyraża ukształtowany w procesach demokratycznych fundament aksjologiczny systemu prawa, zbudowany w oparciu o konglomerat wartości zewnętrznych. Ten fundament aksjologiczny tworzy zespół podstawowych wartości wewnętrznych prawa, wyrażonych w konstytucji, stanowiący punkt odniesienia dla ustalania wartości wewnętrznych wyrażanych w normach znajdujących się na niższych szczeblach hierarchii aktów normatywnych. Normy te wyrażają więc wartości bardziej szczegółowe. Tworzy się hierarchiczna struktura wartości: fundament aksjologiczny danej społeczności (kompleks wartości zewnętrznych prawa) - fundamentalne wartości wewnętrzne wyrażone w ustawie zasadniczej - wartości szczegółowe wyrażone w normach aktów prawnych niższej rangi.

Zagadnieniem wymagającym rozważenia jest tryb wprowadzania wartości do systemów prawa, na czele z aksjologią ustawy zasadniczej. We współczesnych warunkach tryb taki musi mieć postać zinstytucjonalizowanych mechanizmów władzy demokratycznej. Mechanizmy te zakładają, że ciała reprezentujące członków społeczeństwa w strukturze organów państwowych stanowią zespoły o poglądach reprezentatywnych w stosunku do poglądów reprezentowanej populacji ${ }^{5}$. W ten sposób aksjologiczny fundament społeczeństwa znalazłby instytucjonalny wyraz w aksjologii porządku prawnego. Model ten jest oczywiście daleki od doskonałości, opiera się na pewnych założeniach idealnych i nie wyklucza niebezpieczeństwa instrumentalnego wykorzystania mechanizmów demokratycznych do realizacji partykularnych interesów określonych grup. Zjawiskom tym ma przeciwdziałać istnienie fundamentu porządku prawnego w postaci konstytucji, której zmiana wymaga znacznie szerszego konsensu politycznego niż wydanie aktu prawnego niższego rzędu, a także istnienie mechanizmu „strażnika” tego fundamentu w postaci sądu (trybunału) konstytucyjnego.

Odnośnie do relacji pojęciowej dóbr i wartości można ujmować pierwsze z tych pojęć „,materialnie”, co sugerowałoby że pojęcie wartości powinno być odnoszone do niematerialnych przedmiotów ocen. Takie ujęcie nie ma jednak większej wartości poznawczej, nic też nie daje z metodologicznego punktu widzenia. Można wskazać w języku prawniczym (a nawet prawnym) użycia terminu dobro w konotacji nie powiązanej z przedmiotem materialnym - np. dobro wspólne (por. preambułę Konstytucji $R P$ ). Z drugiej strony termin wartość odnoszony może być do ocen przedmiotów materialnych (np. wartość materialna skwantyfikowana w pieniądzu). Nie wydaje się zatem błędem utożsamianie tych pojęć w sytuacji, gdy mówimy o dobrach i wartościach prawnie chronionych ${ }^{6}$.

${ }_{5}^{5}$ Por. Z. Ziembiński, Wartości..., s. 26.

${ }^{6}$ Podobnie M. Zdyb, Prawny interes jednostki w sferze materialnego prawa administracyjnego, Lublin 1991, s. 23. 
W konsekwencji można zatem przyjąć założenie terminologiczne, że w analizowanym aspekcie konfliktu pojęcie dóbr i wartości prawnie chronionych będzie rozumiane jako uosobienie pewnych pozytywnie ocenianych stanów rzeczywistości (kompleksów takich stanów), będących przedmiotem dążeń jednostek lub zbiorowości, których normatywne określenie (w tekstach aktów prawnych) przybiera postać tzw. pojęć niedookreślonych lub klauzul generalnych (np. wartość ładu przestrzennego, zrównoważonego rozwoju).

Teoretycy państwa i prawa wskazują, że podłoże powstających w życiu społecznym konfliktów stanowi dysproporcja pomiędzy ujawnionymi potrzebami jednostek i grup społecznych oraz możliwościami ich zaspokojenia, determinowanymi ograniczoną ilością pożądanych dóbr. „Zachowanie spójności ukła$\mathrm{du}$ społecznego wymaga $\mathrm{w}$ tych warunkach wytworzenia takiego mechanizmu podziału dóbr oraz organizacji działań w skali zbiorowej, który byłby w stanie zapewnić dynamiczną równowagę układu, mimo różnorodnych konfliktów dezintegrujących ten układ"7. Co więcej, teoretycy twierdzą wręcz, że prawo może działać tylko w warunkach konfliktu interesów. Nie ma możliwości stworzenia kompletnej regulacji stosunków społecznych pomijającej lub lekceważącej istnienie konfliktów. Koncepcja taka musiałaby się opierać na irracjonalnym założeniu idealnych zarządzających (prawodawcach) i idealnych zarządzanych (jednostkach) ,wyzbytych wszelkich tendencji indywidualistycznych, żyjących w obfitości dóbr i nie podlegających żadnym przeobrażeniom".

Istota konstrukcji państwa i władzy państwowej opiera się zatem na zjawisku rozwiązywania konfliktów. Muszą powstać trwałe mechanizmy selekcji i hierarchizacji potrzeb i dążeń, skoro ich jednoczesne zaspokojenie nie jest możliwe w warunkach ograniczonej ilości dóbr. Konieczne są dalej mechanizmy opanowywania konfliktów dla utrzymania spójności układu społecznego. Wreszcie niezbędne jest organizowanie współdziałania jednostek i grup dla zaspokojenia przynajmniej pewnego minimum potrzeb społecznych".

Pod pojęciem konfliktu rozumie się z reguły taki układ wartości, w którym wykluczają się one wzajemnie bądź też realizacja jednych wyklucza realizację innych $^{10}$.

Konflikt dóbr i wartości chronionych prawem to konflikt natury aksjologicznej. Jednym z jego pierwotnych źródeł jest pluralizm wartości stanowiących fundament systemów prawnych opartych na poszanowaniu godności osoby ludzkiej i jej praw podstawowych. Demokratyczne państwo prawa jest oparte na skom-

${ }^{7}$ H. Groszyk, A. Korybski, Konflikt interesów i prawo, Warszawa 1990, s. 8 i 16.

8 Por. program socjologicznej jurysprudencji Roscoe Pounda omawiany przez H. Groszyka i A. Korybskiego, op. cit., s. 33.

9 Ibidem, s. 16.

${ }_{10}$ M. Wyrzykowski, Pojęcie interesu społecznego $w$ prawie administracyjnym, Warszawa 1986, s. 164. 
plikowanej aksjologii, starającej się pogodzić potrzeby społeczności i wolności jednostki. Zróżnicowanie postrzegania, ocen i postaw poszczególnych jednostek skutkuje zróżnicowaniem systemów wartości, którymi kierują się również przy podejmowaniu decyzji dotyczących funkcjonowania w zbiorowości. Spójny i stabilny system prawny musi opierać się na pewnym fundamencie aksjologicznym, na pewnych wartościach i dobrach uznawanych za godne ochrony prawnej przez przynajmniej większość społeczeństwa ${ }^{11}$. Nawet jednak między tymi fundamentalnymi wartościami i dobrami może pojawić się konflikt. Są one ujęte w aktach normatywnych tworzących system prawny (na czele z konstytucją, która ma być odzwierciedleniem aksjologii całego systemu prawnego państwa) w sposób abstrakcyjny. Realne stosunki społeczne konkretyzują te wartości i dobra w konkretne relacje. Stąd w danych, określonych warunkach społecznych uwzględnienie w pełni wszystkich wartości tworzących abstrakcyjnie ujęty fundament aksjologiczny porządku prawnego nie jest możliwe. Dochodzi w ten sposób do kolizji dóbr i wartości prawnie chronionych.

Problem konfliktu wartości i dóbr chronionych w prawie komplikuje się współcześnie jeszcze bardziej z uwagi na zjawisko multicentryczności systemów prawa, opartych na wielości ośrodków decydujących co do stanowienia prawa i wyznaczania kierunków jego wykładni ${ }^{12}$. Ponadpaństwowe systemy prawne opierają się również na fundamencie aksjologicznym w postaci pewnego kompleksu wartości wspólnego wszystkim porządkom prawnym państw członkowskich. Bez wspólnoty wartości żaden taki system nie mógłby funkcjonować. Biorąc pod uwagę fakt, że systemy wewnętrzne są już pewnym kompromisem wartości z uwagi na indywidualizm jednostek, znalezienie wspólnego mianownika aksjologicznego dla systemu ponadpaństwowego, łączącego systemy wewnętrzne jest jeszcze trudniejsze. Co więcej - przekazanie przez państwa pewnej części ich suwerenności (suwerennych atrybutów) na organizm ponadpaństwowy oznacza, że co najmniej w pewnym zakresie kształtowanie aksjologii ponadpaństwowego systemu prawnego leżeć będzie w gestii organów podmiotu ponadpaństwowego. W efekcie może dochodzić nawet do konfliktu fundamentalnych wartości pomiędzy tymi systemami. Problem zaostrza jeszcze bardziej fakt, że koncepcja multicentrycznego systemu prawnego zakłada nie odrębność obydwu tych systemów (wewnętrznego i zewnętrznego), ale ich współistnienie.

Pluralizm aksjologiczny nie jest jedynym czynnikiem rodzącym konflikty dóbr i wartości prawnie chronionych. Źródłem konfliktów może być również naturalne

11 Jak pisze M. Zdyb (op. cit., s. 209), „,wspólnotę tworzy nie tylko fakt istnienia obok siebie i wspólnego działania wielu ludzi podporządkowanych określonej władzy, ale i także fakt pewnej łączności duchowej, wspólnego poszanowania wartości interpersonalnych łączących przeżycia społeczne osób. Państwo jest taką wspólnotą gdy jest państwem naturalnym w sensie wartości będących interpersonalnym łącznikiem.

12 E. Łętowska, Multicentryczność wspótczesnego systemu prawa i jej konsekwencje, „Państwo i Prawo" 2005, nr 4, s. 3-4. 
zjawisko niespójności systemów prawnych, wynikające z faktu, że system prawny nie jest w stanie odwzorować bogactwa potencjalnych stosunków społecznych i odpowiednio sprawnie reagować na ich fluktuacje oraz pojawiające się w ich łonie konflikty. Ponadto $w$ decyzjach prawotwórczych zawsze tkwi pewien element niepewności, czego efektem może być niezgodność unormowań z powszechnie akceptowanymi ocenami i wartościami tkwiącymi w świadomości społecznej. Wreszcie niektóre normowane zjawiska społeczne cechuje szczególna konfliktogenność, czego dobrym przykładem jest właśnie sfera planowania i zagospodarowania przestrzennego ${ }^{13}$.

Pojęciem prawnym (języka aktów normatywnych) jest pojęcie interesu, ono bowiem w bardziej bezpośredni sposób wyraża kierunki dążeń jednostek i zbiorowości. Stąd i zainteresowania przedstawicieli doktryny prawa (w tym zwłaszcza administracyjnego) koncentrują się bardziej na pojęciu konfliktu interesów.

Relacja pomiędzy pojęciami dóbr i wartości prawnie chronionych oraz pojęciem interesu nie jest jednolita i zależy od sposobu ujęcia. $Z$ jednej strony można wskazać, że interes publiczny $\mathrm{i}$ interes jednostki same w sobie stanowią wartości, które podlegają ochronie prawnej. Takie znaczenie pojęcia interesów będą miały w wypowiedziach (np. orzeczniczych, doktrynalnych), które wskazują, że jakieś regulacje prawne mają służyć ochronie interesu publicznego lub indywidualnego, czyli są to wartości, które mają być chronione danymi przepisami, które dane przepisy mają realizować, gwarantować.

$\mathrm{Z}$ drugiej strony pojęcie interesu często thumaczone jest jako potrzeba osiągnięcia pewnego dobra, pewnej wartości ${ }^{14}$. Pojęcie wartości (dobra) staje się w tym ujęciu składową pojęcia interesu, albo odwrotnie - interes zbiorczą emanacją wartości (dóbr) ważnych dla jednostki (społeczności) ${ }^{15}$. Poprzez określone wartości wyrażają się ogólniejsze i bardziej abstrakcyjne pojęcia interesów. Innymi słowy prawna ochrona interesu publicznego czy indywidualnego wymaga prawnej ochrony całego szeregu wartości i dóbr, które są składową tych interesów jako przedmiot potrzeb i dążeń jednostki lub zbiorowości. Dla przykładu w sferze planowania i zagospodarowania przestrzennego na ogólniejszą kategorię wartości interesu publicznego składają się bardziej szczegółowe kategorie pojęciowe wyrażające dobra i wartości prawnie chronione m.in. ładu przestrzennego, zrównoważonego rozwoju itd. Z kolei na kategorię interesu indywidualnego składać się będzie przede wszystkim wartość (dobro chronione) prawa własności (i innych praw majątkowych na nieruchomościach), stanowiące materialny fundament wolności jednostki. Można zatem powiedzieć, że szczegółowe dobra i wartości

${ }_{13}$ Por. podobnie, ale w odniesieniu do konfliktu interesów (społecznego i indywidualnego) - M. Zdyb, op. cit., s. 221-228.

14 Por. A.S. Duda, Interes prawny w polskim prawie administracyjnym, Warszawa 2008, s. 10 13; M. Zdyb, op. cit., s. 22 i n.

15 Ibidem, s. 30. 
chronione stają się w tym ujęciu dyrektywą kierunkową interpretacji norm prawnych, pozwalającą ocenić, jaka jest w konkretnym przypadku treść ogólniejszej wartości chronionej interesu publicznego bądź indywidualnego ${ }^{16}$. Interes publiczny czy jednostkowy pojmowany jako sama w sobie wartość (dobro) chronione prawem będzie stanowił zatem $\mathrm{z}$ reguły kompleks jednostkowych wartości szczegółowych, czyli pozytywnie ocenianych stanów rzeczywistości, stanowiących cel dążeń jednostkowych lub zbiorowych.

Niestety opisanej relacji kategorii pojęciowych interesu publicznego oraz dóbr i wartości prawnie chronionych wydaje się nie dostrzegać ustawodawca na gruncie ustawy o planowaniu i zagospodarowaniu przestrzennym ${ }^{17}$. W katalogu elementów, które powinny być uwzględniane w planowaniu i zagospodarowaniu przestrzennym (art. 1 ust. 2 u.p.z.p.) wymieniono oddzielnie potrzeby interesu publicznego (pkt 9) oraz takie wartości i dobra chronione jak: wymagania ładu przestrzennego, w tym urbanistyki i architektury; walory architektoniczne i krajobrazowe; wymagania ochrony środowiska, w tym gospodarowania wodami i ochrony gruntów rolnych i leśnych; wymagania ochrony dziedzictwa kulturowego i zabytków oraz dóbr kultury współczesnej; wymagania ochrony zdrowia oraz bezpieczeństwa ludzi i mienia, a także potrzeby osób niepełnosprawnych; walory ekonomiczne przestrzeni. Zakładając racjonalność ustawodawcy trzeba byłoby dojść do kuriozalnego wniosku, że wymienione wartości i dobra stanowią odrębne kategorie znaczeniowe od pojęcia interesu publicznego. Trudno wskazać jaką treść normatywną odrębną od kategorii pojęciowej interesu publicznego mają takie wartości (dobra) jak ład przestrzenny, ochrona środowiska, ochrona dziedzictwa kulturowego i zabytków itd. Są to w istocie elementy składowe tworzące ogólniejszą wartość interesu publicznego. Należało zatem użyć sformułowania: „inne potrzeby interesu publicznego”, co wskazywałoby na to, że w planowaniu i zagospodarowaniu przestrzennym należy uwzględniać również inne dobra i wartości, nie wymienione wcześniej, których ochrona stanowi realizację wartości interesu publicznego ${ }^{18}$.

${ }^{16}$ Każde prawidłowe stosowanie normy prawnej wymaga nazwania i określenia treści wartości realizowanych przez daną normę (ściślej: których realizacji norma ma służyć) - por. S. Fundowicz, Aksjologia prawa administracyjnego, [w:] J. Zimmermann (red.), Koncepcja systemu prawa administracyjnego, Warszawa 2007, s. 634.

17 Ustawa z dnia 27 marca 2003 r. o planowaniu i zagospodarowaniu przestrzennym; Dz. U. z 2012, poz. 647, ze zm. (dalej: u.p.z.p.).

18 Podobnie krytycznie o katalogu z art. 1 ust. 2 u.p.z.p. wyraża się H. Izdebski, który dodatkowo podważa zastosowaną przez ustawodawcę gradację wartości, według której wartość interesu publicznego znalazła się na przedostatnim miejscu w katalogu. H. Izdebski, Interes publiczny a interes prywatny. Uwagi na tle legalnej definicji interesu publicznego w ustawie o planowaniu i zagospodarowaniu przestrzennym, [w:] T. Giaro (red.), Interes publiczny a interes prywatny w prawie, Warszawa 2013, s. 149-151; tenże, Prawo własności w planowaniu zagospodarowania przestrzeni, [w:] I. Zachariasz (red.), Kierunki reformy prawa planowania i zagospodarowania przestrzennego, Warszawa 2012, s. 21-23. 
Istnieją dwa sposoby spojrzenia na zjawisko konfliktu interesów w prawie administracyjnym. Pierwszy z nich wynika ze zjawiska osobistego zaangażowania funkcjonariusza (urzędnika) w sprawę, którą w ramach posiadanych kompetencji rozstrzyga (w szerokim rozumieniu tego słowa, nie tylko poprzez indywidualny akt administracyjny). Jak ujmuje to P.J. Suwaj „o konflikcie interesów w działalności administracji publicznej mówimy w sytuacji, gdy funkcjonariusz publiczny podejmujący rozstrzygnięcie sprawy bądź też uczestniczący w przygotowaniu tego rozstrzygnięcia ma lub może mieć interes w sposobie rozstrzygnięcia tej sprawy" ${ }^{19}$. U źródeł konfliktu leżeć będzie albo kwestia rozstrzygania we własnej sprawie, albo zjawiska natury korupcyjnej.

W drugim spojrzeniu elementy subiektywne tracą znaczenie - kluczowe staje się zderzenie wartości i dóbr chronionych. Chodzi o sytuacje, gdy pojawia się zjawisko konkurencyjności tych wartości - ochrona jednej spowoduje odrzucenie lub umniejszenie innej. Oczywiście w konflikcie o tle personalnym konflikt wartości również jest widoczny - w uproszczonym ujęciu - z jednej strony wartości bezstronności, transparentności działań władzy publicznej, z drugiej - dążenie do realizacji indywidualnej sfery potrzeb i wolności urzędnika jako jednostki zaangażowanej w konflikt. Inne są jednak źródła tego konfliktu (właśnie elementy subiektywne), inne kryteria analizy, inne wreszcie metody zapobiegania czy zwalczania zjawiska.

Większość wypowiedzi doktrynalnych skupia się na zjawisku konfliktu interesów jako polaryzacji interesu publicznego i indywidualnego, co jest zrozumiałe, gdyż ta postać jest najczęściej spotykaną, aczkolwiek nie jedyną. Po pierwsze możliwy jest również konflikt różnych wartości w ramach interesu publicznego - jest to wówczas problem właściwych metod realizacji interesu publicznego, która z kolidujących wartości $\mathrm{w}$ danym przypadku jest istotniejsza z punktu widzenia interesu publicznego, która zaś musi ustąpić. Może to być również konflikt natury podmiotowej, gdy interes publiczny nabiera różnych treści ze względu na podmiot, do którego się odnosi (konflikt interesu państwowego i interesu wspólnoty samorządowej $)^{20}$. Po drugie, choć bardziej jest to widoczne w relacjach regulowanych prawem cywilnym, to jednak również w stosunkach prawnych natury administracyjnej niekiedy mocno zarysowuje się konflikt różnych interesów indywidualnych, czego najdobitniejszym przykładem są procesy inwestycyjne i wynikające na tym tle konflikty sąsiedzkie.

Zasadniczą determinantą wyznaczającą relacje interesu publicznego i jednostkowego jest model państwa. Ekstremalne relacje to wizje skrajnie uniwersalistyczne, podporządkowujące jednostkę państwu, gdzie wolność jednostki sięga do granic kolizji z interesem publicznym lub ujęcie skrajnie indywidualistyczne, gdzie to wolność jednostki staje się wartością nadrzędną. Pierwsza koncepcja zosta-

19 P.J. Suwaj, Konflikt interesów w administracji publicznej, Warszawa 2009, s. 52.

20 Jak podkreśla M. Zdyb (op. cit., s. 216), przy założeniu podmiotowości prawnej samorządu terytorialnego upada teza o tożsamości interesu publicznego i celu państwa. 
ła całkowicie zdezawuowana historycznymi doświadczeniami systemów politycznych starających się ją urzeczywistnić. Również druga musi ulec odrzuceniu, stoi bowiem w sprzeczności ze społeczną naturą osobowości człowieka, który w naturalny sposób odczuwa potrzebę łączenia się z szerszymi wspólnotami, poczynając od rodziny, a kończąc na państwie, a nawet wspólnotach ponadpaństwowych.

Właściwym ujęciem wydaje się wizja poszukująca kompromisu, ale i dopuszczająca konflikt interesów, oparta na personalistycznym założeniu, że zarówno osoba jaki i społeczność stanowią byty naturalne i wzajemnie zależne. Jak trafnie wskazuje M. Zdyb, nie jest celowe „ujmowanie relacji jednostka - Państwo w kategoriach gry o sumie zerowej, a więc w kategoriach pełnej konkurencyjności, zakładającej, że jeżeli państwo coś zyskuje, to obywatel traci” bądź odwrotnie. „Interesy te nie muszą być konkurencyjne. Brak konkurencyjności nie wyklucza jednak ich konfliktowości"21.

Rozstrzygnięcie konfliktu interesów w prawie administracyjnym (szczegółowych dóbr i wartości chronionych będących przedmiotem dążeń wyrażających te interesy) nie jest abstrakcyjną operacją myślową lecz wymaga odniesienia do konkretnych relacji społecznych. W doktrynie wskazuje się na pewne podstawowe dyrektywy kierunkowe rozstrzygania tych konfliktów. Kluczową z nich jest ważenie interesów (wartości, dóbr chronionych), nakaz ich kojarzenia i harmonizowania, poszukiwania rozwiązań kompromisowych ${ }^{22}$. Jak pisze M. Wyrzykowski, „złożony układ stosunków społecznych i złożona treść poszczególnych typów interesów nie pozwalają na przyjęcie założenia nadrzędności czy też dominacji jakiegokolwiek typu interesu jako zasady prawa administracyjnego czy zasady działania administracji”. W punkcie wyjścia procesu decyzyjnego trzeba przyjąć domniemanie równowagi interesów, dopiero uwzględnienie całokształtu okoliczności sprawy pozwala na stwierdzenie przewagi któregoś z interesów ${ }^{23}$.

W teorii prawa metoda ważenia wartości jest uznawana za ogólną metodę wykładni, stosowaną we wszystkich gałęziach prawa, w sytuacji konieczności wyboru pomiędzy wartościami. W tym ujęciu sens prawodawstwa polega na rozstrzyganiu kolidujących interesów (wartości). Rozstrzygnięcie kolizji zakłada ustalenie relatywnej wagi określonych interesów (wartości), przypisanej przez prawodawcę i przeniesienie tych ustaleń na rozstrzygany przypadek. Można wyodrębnić ważenie abstrakcyjne, zmierzające do ustalenia relatywnej wagi rozważanych wartości niezależnej od konkretnej sytuacji oraz ważenie konkretne, gdzie

${ }^{21}$ M. Zdyb, op. cit., s. 209.

22 J. Borkowski, [w:] J. Borkowski, J. Jendrośka, R. Orzechowski, A. Zieliński, Kodeks postępowania administracyjnego, Warszawa 1985, s. 69; S. Rozmaryn, O zasadach ogólnych kodeksu postępowania administracyjnego, „Państwo i Prawo” 1961, nr 12, s. 891; M. Wyrzykowski, op. cit., s. 174-179, M. Zdyb, op. cit., s. 232, 240.

${ }^{23}$ M. Wyrzykowski, op. cit., s. 183 i 177. Wskazuje przy tym, że „Wyważenie interesów jest przede wszystkim zadaniem ustawodawcy z tej racji, że proces ustawodawczy stwarza w warunkach demokratycznej reprezentacji społecznej optymalne warunki do rozważenia, wyważenia i uwzględnienia zróżnicowanych społecznie doniosłych celów (s. 174). 
ustalenia czynione są w odniesieniu do konkretnej sytuacji. Ważenie konkretne zakłada dokonanie ważenia abstrakcyjnego. Proces ważenia trzeba rozpocząć od stwierdzeń uogólniających na temat relacji pierwszeństwa kolidujących wartości, a następnie zbadać, czy te twierdzenia nie powinny być skorygowane ze względu na okoliczności konkretnego przypadku²4.

Interesującą koncepcję rozstrzygania kolizji dóbr prawnie chronionych zaprezentował T. Gizebrt-Studnicki. Przyjmuje dwa istotne założenia. Po pierwsze wyodrębnia zasady prawne i reguły prawne. Specyfika zasad prawnych sprowadza się do tego, że ich spełnianie jest stopniowalne. Po drugie, stawia tezę, że dobra prawnie chronione są wyrażone w postaci zasad prawnych, nakazujących ochronę tych dóbr. Kolizja dóbr to zatem kolizja zasad. Kolizja reguł prawnych rozstrzyga się w sposób abstrakcyjny, bez odniesienia do konkretnego stanu faktycznego, przy zastosowaniu norm kolizyjnych i prowadzi w efekcie do wyboru tylko jednej z reguł jako obowiązującej. Rozstrzygnięcie kolizji zasad prawnych odbywa się w odniesieniu do konkretnego stanu faktycznego, w którym jedna z zasad może uzyskać pierwszeństwo i znaleźć zastosowanie kosztem drugiej, która jednak nie przestaje obowiązywać i może uzyskać pierwszeństwo w innym stanie faktycznym. Ponadto przyjęcie pierwszeństwa jednej z zasad nie wyklucza uwzględnienia $\mathrm{w}$ danej sytuacji również drugiej. W tym przypadku dobro chronione przez zasadę, która zyskała pierwszeństwo jest realizowane z zachowaniem kryterium proporcjonalności - przy możliwie najmniejszym uszczerbku dla dobra, które musi ustąpić.

Dla rozstrzygnięcia kolizji dóbr nie jest wystarczające stworzenie ich abstrakcyjnej hierarchii, opierającej się na odtworzeniu systemu aksjologicznego leżącego u podstaw systemu prawnego. Waga dóbr w konkretnych, różnych stanach faktycznych może być różna, w efekcie czego może się okazać, że w danym stanie faktycznym dobro niższe w hierarchii abstrakcyjnej uzyska większą wagę i co za tym idzie - pierwszeństwo. Zasadniczy postulat stanowiący podstawę rozstrzygania dóbr formułuje się następująco: „im wyższy jest stopień naruszenia lub niespełnienia jednego z kolidujących dóbr, tym ważniejsze musi być zrealizowanie drugiego dobra". Istotną kwestią jest zapewnienie, aby konflikt dóbr rozstrzygać w oparciu o kryteria intersubiektywne, a więc poddające się kontroli prawidłowości zastosowania. Rozstrzyganie kolizji wymaga więc przyjęcia pewnych podstawowych wymogów, dających gwarancję obiektywności ocen. Zalicza się do nich:

1) nakaz właściwej identyfikacji dóbr (należyte ich określenie ich treści);

2) prawidłowe ustalenie relacji hierarchicznych między dobrami (dlaczego jednym przypisuje się in abstracto większą wagę niż innym);

3) wyjaśnienie kryteriów szacowania wagi poszczególnych dóbr w warunkach konkretnego stanu faktycznego ${ }^{25}$.

${ }^{24}$ T. Spyra, Granice wyktadni prawa, Kraków 2006, s. 239-240.

${ }_{25}$ T. Gizbert-Studnicki, Konflikt dóbr i kolizja norm, „Ruch Prawniczy, Ekonomiczny i Socjologiczny" 1989 , nr 1, s. 1-14. Por. koncepcje rozstrzygania kolizji zasad i konfliktu reguł R. Alexy'ego (w pol. wyd.: Teoria praw podstawowych, Warszawa 2010, s. 79 i n.). 
Punktem wyjścia dla procesu porównywania, kojarzenia, ważenia interesów jest ich sprowadzenie do tej samej płaszczyzny odniesienia. Nie da się porównywać zjawisk, które funkcjonują na różnych poziomach uogólnienia. Nie można racjonalnie odmawiać zaspokojenia konkretnego interesu indywidualnego z powołaniem się na abstrakcyjnie ujęty interes publiczny ${ }^{26}$. Myśl tę można odnieść jednakowo do konfliktu wartości i dóbr prawnie chronionych. Na przykładzie konfliktu na tle planowania i zagospodarowania przestrzennego - ograniczenie konkretnych uprawnień jednostki objętych prawem własności nie może być uzasadnione abstrakcyjnie ujętą wartością ładu przestrzennego. Konieczne jest nadanie tej wartości konkretnych treści w danych warunkach - jakie konkretne przyczyny sprawiają, że w konkretnej sytuacji dobro jednostki musi zostać ograniczone ze względu na wartości realizujące interes publiczny.

Tam gdzie jedna wartość (dobro) musi ulec (podporządkować się) innej konieczne jest respektowanie nakazu proporcjonalności - spośród wielu możliwych rozwiązań należy wybierać te, które pozwolą w wystarczającym stopniu chronić dobro nadrzędne przy możliwie najmniejszym uszczupleniu dobra, które musi zostać poświęcone ${ }^{27}$.

M. Wyrzykowski dokonał klasyfikacji postaci wadliwego wyważenia interesu społecznego i jednostkowego, która z powodzeniem może być odniesiona do błędów ważenia wartości i dóbr chronionych, poprzez które interesy te realizują się. Błędy te mogą polegać na: braku w ogóle wyważenia interesów (wartości, dóbr); nieuwzględnieniu $\mathrm{w}$ procesie wyważenia wszystkich wchodzących w grę interesów (wartości, dóbr); bezpodstawnym przyjęciu a priori dominacji któregokolwiek typu interesów (wartości, dóbr); naruszeniu reguł równości wobec prawa poprzez uwzględnienie jednego z interesów (wartości, dóbr) w sposób odmienny niż innych (zastosowanie nierównych kryteriów oceny); naruszeniu zasady sprawiedliwości ${ }^{28}$.

\section{Nadużycie władztwa planistycznego jako przykład wadliwego wyważenia dóbr i wartości prawnie chronionych}

\section{Istota władztwa planistycznego}

Konieczność władczej reglamentacji gospodarowania przestrzenią jest podyktowana jej ograniczonym charakterem ${ }^{29}$. Zadaniem publicznym staje się administrowanie celem optymalnego wykorzystania ograniczonej przestrzeni, zgodne

${ }^{26}$ Por. M. Zdyb, op. cit., s. 234.

27 M. Wyrzykowski, op. cit., s. 177.

28 Ibidem, s. 179.

29 Por. M. Kotulski, Problemy w ksztaltowaniu przestrzeni w procesie planowania i zagospodarowania przestrzennego, [w:] I. Niżnik-Dobosz (red.), Przestrzeń i nieruchomości jako przedmiot prawa administracyjnego. Publiczne prawo rzeczowe, Warszawa 2012, s. 38. 
z wymogami zasady zrównoważonego rozwoju. Jest to zatem naturalne podłoże do tworzenia się konfliktów interesów, co rodzi konieczność rozstrzygnięcia kolizji stanowiących ich podstawę dóbr i wartości chronionych prawnie.

Współcześnie reglamentacja ta przyjmuje z reguły postać zdecentralizowaną, w której zasadniczy zrąb kompetencji planistycznych powierzony jest organom administracji samorządowej. Taki model, choć nie wyłącza aktów planowania na wyższym szczeblu, w lepszym stopniu pozwala uwzględnić w tym procesie specyfikę uwarunkowań lokalnych.

Fundamentem zdecentralizowanego systemu zarządzania przestrzenią jest samodzielność planistyczna gminy, będąca elementem ogólniejszej zasady samodzielności gminy, która z kolei stanowi fundament ustrojowy samorządu terytorialnego w Polsce. Zastrzega się przy tym, że samodzielność planistyczna gminy nie może być jednak utożsamiana $\mathrm{z}$ autonomią, doznaje bowiem szeregu ograniczeń $^{30}$. Samodzielności jednostek samorządu terytorialnego, jako wartości chronionej i gwarantowanej konstytucyjnie, nie wolno absolutyzować, skoro jednostki samorządu terytorialnego wykonują zadania publiczne „w ramach ustaw”31.

Podstawowym elementem samodzielności gminy w sferze planowania i zagospodarowania przestrzeni jest tzw. władztwo planistyczne. Doktrynalne definicje władztwa planistycznego akcentują trzy główne elementy: źródło władztwa (upoważnienie ustawowe), jego treść (ustalanie przeznaczenia i sposobu zagospodarowania określonego terenu) oraz wynikający z samego pojęcia element imperium, możliwości władczego, jednostronnego oddziaływania na sferę prawną jednostek będących adresatami aktów gminy. Przykładowo, w ujęciu Z. Niewiadomskiego władztwo planistyczne gminy oznacza przekazanie przez ustawodawcę gminie kompetencji w zakresie władczego przeznaczania i ustalania zasad zagospodarowania terenu w drodze aktu prawnego wiążącego (aktu prawa miejscowego - miejscowego planu zagospodarowania przestrzennego, a w przypadku braku planu - w drodze decyzji o warunkach zabudowy i zagospodarowania terenu) ${ }^{32}$.

W podobny sposób istotę władztwa planistycznego określa orzecznictwo, akcentując elementy ustawowego upoważnienia, jego granic i podlegającej ochronie

${ }^{30}$ W wyroku z 18 stycznia 1992 r. (III RN 192/00, OSNAP i US 2002, nr 15, poz. 346) SN stwierdził, że chociaż ustalenie zagospodarowania przestrzennego należy do zadań własnych gminy, to z prawnej kwalifikacji tego zadania własnego gminy nie wynika, że gmina ustalając przeznaczenie i zasady zagospodarowania terenu w planach zagospodarowania przestrzennego posiada graniczącą z autonomią planistyczną swobodę w kształtowaniu tych zasad.

31 Wyrok NSA z 19 czerwca 2012 r., II OSK 814/12. Przytaczane w artykule orzeczenia, jeżeli nie wskazano innego miejsca publikacji, pochodzą z Centralnej Bazy Orzeczeń Sądów Administracyjnych (CBOSA).

32 Z. Niewiadomski, Planowanie przestrzenne, Warszawa 2003, s. 90; tenże (red.), Planowanie i zagospodarowanie przestrzenne. Komentarz, Warszawa 2013, s. 28. Podobnie M. Szewczyk, [w:] Z. Leoński, M. Szewczyk, Podstawowe instytucje planowania przestrzennego i prawa budowlanego, Poznań 1997, s. 48; Z. Leoński, M. Szewczyk, Zasady prawa budowlanego i zagospodarowania przestrzennego, Bydgoszcz-Poznań 2002, s. 20). 
samodzielności realizacji władztwa. W jednej z pierwszych wypowiedzi określających istotę analizowanego pojęcia Naczelny Sąd Administracyjny stwierdził:

Mając wyłączną kompetencję do planowania miejscowego, gmina może, pod warunkiem że działa w granicach i na podstawie prawa, samodzielnie kształtować sposób zagospodarowania obszaru podlegającego jej władztwu planistycznemu, jeżeli oczywiście władztwa tego nie nadużywa, a organy państwa, w tym Naczelny Sąd Administracyjny, nie mogą jej władztwa planistycznego pozbawić ${ }^{33}$.

\section{Granice władztwa planistycznego}

Realizacja władztwa planistycznego gminy powinna w założeniu stanowić wyraz balansowania określonych wartości. Z jednej strony występuje chroniona wartość interesu publicznego, wyrażającego się w konieczności zaspokajania przez gminę zbiorowych potrzeb wspólnoty samorządowej w zakresie optymalnego wykorzystania przestrzeni, w zgodzie z zasadą zrównoważonego rozwoju. Władztwo gminy w tym zakresie jest wyrazem jej samodzielności (planistycznej), a zatem wartości gwarantowanej konstytucyjnie. Z drugiej strony - z uwagi na możliwość bardzo daleko idących ingerencji w sferę jednostki - pojawia się konieczność ochrony interesu indywidualnego. Szczególnego znaczenia nabiera ochrona własności jako materialnego fundamentu wolności jednostki.

Trafnie ujął to NSA w następującym wywodzie:

Gmina to wspólnota mieszkańców, a jej zadaniem podstawowym jest zaspokajanie potrzeb tej wspólnoty (art. 166 ust. 1 Konstytucji). Oznacza to, że prowadząc konkretną politykę w ramach przyznanych kompetencji, w tym planistyczną, gmina obowiązana jest zwracać uwagę na potrzeby wszystkich mieszkańców. Każdy bowiem mieszkaniec gminy, członek wspólnoty samorządowej, ma prawo oczekiwać, że jego interesy będą brane pod uwagę w działaniach gminy. Na gruncie planowania przestrzennego konieczne jest zatem takie wyważenie interesów aby w jak największym stopniu zabezpieczyć i rozwiązać potrzeby wspólnoty, jednak w jak najmniejszym naruszając prawa właścicieli nieruchomości objętych planem”34.

Konieczność ważenia kolidujących wartości i interesów każe limitować zakres władztwa. Granice władztwa planistycznego gminy są wyznaczane trzema determinantami: (1) normą kompetencyjną, kreującą władcze kompetencje planistyczne; (2) normami zadaniowymi, adresowanymi do gminy i jej organów, określającymi zadania w zakresie planowania przestrzennego, a więc określającymi sposób korzystania z władztwa; (3) publicznymi prawami podmiotowymi jednostek, w tym w szczególności prawem zabudowy stanowiącym emanację prawa własności.

33 Wyrok NSA z 9 czerwca 1995 r., IV SA 346/93; ONSA 1995, nr 3, poz. 125. Podobnie wyroki NSA z 19 czerwca 2012 r. (II OSK 814/12) i z 22 czerwca 2012 r. (II OSK 878/12).

34 Wyrok NSA z 9 lutego 2010 r. (II OSK 1959/09). Podobnie WSA w Lublinie w wyroku z 28 maja 2013 r., II SA/Lu 1020/12 (nieprawomocny). 
W zakresie pierwszej determinanty - normy kompetencyjnej - istnieją pewne stałe założenia: jej źródłem mogą być wyłącznie akty rangi ustawowej, interpretowane w sposób ścisły, wyłączający jakiekolwiek domniemanie kompetencji. Źródłem kompetencji nie mogą być normy zadaniowe, gdyż z określenia zadań nie wynika automatycznie zdolność do podejmowania określonych działań. Władztwa planistycznego nie można zatem opierać wyłącznie na zadaniach publicznych powierzonych do wykonania gminie ${ }^{35}$.

Źródła kompetencji organów gminy w ramach władztwa planistycznego budzą istotne kontrowersje natury konstytucyjnej, z uwagi na charakter i zakres możliwej ingerencji w sferę prawa jednostki - wszak ustalenia miejscowego planu zagospodarowania przestrzennego kształtują, wraz z innymi przepisami, sposób wykonywania prawa własności nieruchomości ${ }^{36}$. Jest to szeroko dyskutowany i stąd powszechnie znany problem rozumienia nakazu ustawowej formy wprowadzania ograniczeń praw i wolności gwarantowanych Konstytucją. Sprowadza się on do jednego z dwóch wariantów. Według pierwszego wyrażony w przepisach Konstytucji wymóg należy rozumieć dosłownie - „w drodze ustawy”, co oznaczałoby, że tylko normy rangi ustawowej mogą wprowadzać bezpośrednio ograniczenia, akty niższego rzędu mogą jedynie ściśle wykonywać (uściślać w sensie technicznym) regulacje ustawowe. Według drugiego wariantu nakaz konstytucyjny powinien być odczytywany jako „na podstawie ustawy”, co dopuszcza ograniczenia zawarte w aktach podstawowych, wydanych w oparciu o ogólną delegację ustawową (art. 6 ust. $1 \mathrm{i}$ art. 14 u.p.z.p.).

$\mathrm{Z}$ braku miejsca nie wchodząc w szersze rozważania na ten temat i odsyłając w tym zakresie do odpowiedniej literatury ${ }^{37}$ trzeba w tym miejscu wskazać, że jako rozwiązanie tego dylematu proponuje się koncepcję, nie wolną od kontrowersji, która traktuje akty prawa miejscowego wydane na podstawie upoważnienia ustawowego w ścisłej łączności z ustawą, na podstawie której zostały wydane, jako swego rodzaju ,ustawy w znaczeniu materialnym”. Na podstawie upoważnienia

${ }_{35}$ W. Jakimowicz, Władztwo plastyczne gminy - kompetencje, zadania, wolności, „Administracja. Teoria. Dydaktyka. Praktyka" 2012, nr 1, s. 14-17; tenże, Wolność zabudowy w prawie administracyjnym, Warszawa 2012, s. 409-414.

${ }^{36}$ Art. 6 ust. 1 u.p.z.p.

${ }^{37} \mathrm{Za}$ restrykcyjnym pojmowaniem wymogu ustawowej formy ograniczeń wypowiada się konsekwentnie Z. Czarnik - spośród jego kilku opracowań w tej kwestii zob. w szczególności ostatnie - Miejscowy plan zagospodarowania przestrzennego jako podstawa wykonywania własności nieruchomości, „Zeszyty Naukowe Sądownictwa Administracyjnego” 2006, nr 2, s. 42 i n. oraz Istota i zakres władztwa planistycznego gminy, „Administracja” 2010, nr 3, s. 13-16, 18-19. Z kolei wśród głosów opowiadających się za drugą koncepcją można wskazać m.in.: T. Dybowskiego, Ochrona prawa własności na tle konstytucyjnej koncepcji źródet prawa w orzecznictwie Trybunatu Konstytucyjnego, [w:] F. Rymarz (red.), Trybunat Konstytucyjny. Księga XV-lecia, Warszawa 2001, s. 118-119; S. Jarosz-Żukowską, Konstytucyjna zasada ochrony własności, Kraków 2003, s. 181; K. Wojtyczka, Granice ingerencji ustawodawczej w sferę praw człowieka w Konstytucji RP, Kraków 1999, s. 110. 
ustawowego rada gminy może niejako w zastępstwie ustawodawcy wprowadzać powszechnie obowiązujące przepisy prawa, w tym określające granice swobody wykonywania uprawnień właścicielskich do określonego terenu ${ }^{38}$. W podobnym kierunku zmierza argumentacja judykatury, zdaniem której już samo ustawowe upoważnienie do uchwalania miejscowych planów zagospodarowania przestrzennego, w których gminy ustalają przeznaczenie i zasady zagospodarowania terenu, a w konsekwencji ograniczają sposób wykonywania prawa własności, jest wystarczające dla spełnienia konstytucyjnego wymogu ustawowej formy ograniczeńn ${ }^{39}$.

Zakres władztwa planistycznego gminy ograniczają kompetencje planistyczne innych podmiotów. Plan miejscowy jest tylko jednym z kilku aktów tworzących system planowania (obejmujący także szczebel krajowy i wojewódzki). Ponadto poza sferą kompetencji planistycznych gminy pozostają pewne obszary (np. tereny zamknięte, wewnętrzne wody terytorialne, strefy ekonomiczne) ${ }^{40}$.

Kolejnym elementem wyznaczającym sposób korzystania z władztwa planistycznego są normy zadaniowe, adresowane do organów gminy, wyznaczające zadania, jakie gmina powinna realizować w sferze planowania i zagospodarowania przestrzennego. Cecha samodzielności gminy (w kontekście samodzielności planistycznej) determinuje pewien luz decyzyjny w zakresie celowości podejmowanych działań planistycznych. Rolę podstawowego wyznacznika interpretacji norm zadaniowych pełni kryterium lokalnego interesu publicznego (interesu wspólnoty $)^{41}$.

W orzecznictwie podkreśla się, że ustawodawca pozostawia szeroki zakres swobody w zakresie korzystania z władztwa planistycznego, a w szczególności nie formułuje precyzyjnych kryteriów podejmowania rozstrzygnięć planistycznych, poprzestając w tej kwestii na ogólnych wskazaniach zawartych w art. 1 u.p.z.p. Biorąc pod uwagę fakt, że realizacja władztwa planistycznego wiąże się $\mathrm{z}$ ingerencją w sferę prawa własności jednostek, brak precyzyjnych kryteriów możliwej ingerencji nie może powodować dowolności w korzystaniu przez radę gminy z kompetencji w zakresie stanowienia planów miejscowych ${ }^{42}$.

38 W. Jakimowicz, Władztwo ..., s. 20-26, tenże, Wolność zabudowy..., s. 412; Z. Niewiadomski (red.), Planowanie i zagospodarowanie, s. 61.

39 Por. m.in. wyroki NSA z 5 lipca 2005 r. (OSK 1456/04), z 10 maja 2006 r. (II OSK 170/06), z 19 maja 2006 r. (II OSK 207/06), z 8.11.2007 r. (II OSK 909/07), z 15.5.2008 r. (II OSK 1716/07), z 1.6.2012 r. (II OSK 844/12); wyrok WSA w Gdańsku z 29.9.2011 r. (II SA/Gd 978/10); wyrok WSA w Krakowie z 8.9.2009 r. (II SA/Kr 1062/08); wyrok WSA w Poznaniu z 13.5.2009 r. (IV SA/ Po 156/09); wyroki WSA we Wrocławiu z 12.11.2009 r. (II SA/Wr 678/08), z 25.4.2013 r. (II SA/ Wr 134/13).

40 Z. Czarnik, Istota i zakres..., s. 10.

${ }^{41}$ W. Jakimowicz, Władztwo..., s. 31 i 35; tenże, Wolność zabudowy..., s. 419. Podobnie I. Chojnacka (Władztwo planistyczne gminy w orzecznictwie sądów administracyjnych i Trybunału Konstytucyjnego, „Samorząd Terytorialny” 2009, nr 1-2, s. 88), która jako determinantę realizacji zadań w zakresie władztwa planistycznego gminy wskazuje dobro wspólnoty samorządowej.

${ }^{42}$ Por. wyrok WSA w Gliwicach z 17 czerwca 2013 r., II SA/G1 12/13. 
Swoboda realizacji władztwa planistycznego gminy jest ograniczana w przypadkach, gdy normy zadaniowe są precyzowane poprzez przepisy ustaw szczególnych, determinujących sposób wprowadzania ograniczeń w sferze prawnej jednostek (m.in. w zakresie ochrony środowiska, przyrody, zabytków, prawa geologicznego i górniczego $)^{43}$.

Granice władztwa planistycznego wyznaczają także publiczne prawa podmiotowe adresatów rozstrzygnięć planistycznych gminy, ze szczególnym uwzględnieniem prawa zabudowy, rozumianego jako publiczne prawo podmiotowe o charakterze negatywnym, wyrażające się $\mathrm{w}$ roszczeniu o zaniechanie ingerencji w sferę przysługującej jednostce wolności korzystania z nieruchomości ${ }^{44}$.

Jak wskazuje się w literaturze, granice ingerencji w sferę praw jednostki opartej na władztwie planistycznym kształtują się w zróżnicowany sposób, w zależności od tego, czy ingerencja narusza istotę prawa, czy też nie. Ingerencja w samą istotę wolności zabudowy poprzez całkowite pozbawienie możliwości jakiejkolwiek zabudowy nieruchomości musi być traktowana jako forma wywłaszczenia (w szerokim rozumieniu tego pojęcia), dopuszczalna wyłącznie dla realizacji konkretnego, normatywnie uzasadnionego celu publicznego ${ }^{45}$. Z kolei kształtowanie korzystania z prawa własności w sposób nie naruszający istoty tego prawa może opierać się na ogólniejszej kategorii interesu publicznego, z uwzględnieniem zasady proporcjonalności. Granice władztwa planistycznego mogą być w większym zakresie (niż w przypadku celu publicznego) wyznaczane działaniem samego organu wyposażonego w kompetencje planistyczne, co ma zapewnić niezbędną elastyczność działań ${ }^{46}$.

\section{Koncepcja nadużycia władztwa planistycznego}

Jak już wyżej wskazano, wypracowana przez orzecznictwo ${ }^{47}$ koncepcja nadużycia władztwa planistycznego jest dobrym przykładem obrazującym szerszą tezę, w myśl której brak właściwego rozwiązania problemu kolizji dóbr, brak ich

${ }_{43}$ Podobnie T. Bąkowski, Wpływ przemian ustrojowych $w$ Polsce na prawo zagospodarowania przestrzennego (podstawowe problemy), „Samorząd Terytorialny” 2000, nr 1-2, s. 149; Z. Niewiadomski (red.), Planowanie i zagospodarowanie przestrzenne. Komentarz, Warszawa 2009, s. 42-43.

${ }^{4}$ Por. T. Asman, [w:] Z. Niewiadomski (red.), Prawo budowlane. Komentarz, Warszawa 2011, s. 9-91; W. Jakimowicz, Wolność zabudowy..., s. 66; A. Ostrowska, Pozwolenie na budowę, Warszawa 2009, s. 26-27.

45 W. Jakimowicz, Władztwo ..., s. 41-49, tenże, Wolność zabudowy..., s. 421-422.

46 W. Jakimowicz, Władztwo ..., s. 43, 49-52. Szerzej na temat wyodrębnienia pojęciowego kategorii celu publicznego i interesu publicznego zob. W. Jakimowicz, Wyktadnia w prawie administracyjnym, Warszawa 2006, s. 93-94.

${ }^{47}$ Doktrynalne wypowiedzi na temat nadużycia władztwa planistycznego są dość skromne. Zdaniem W. Jakimowicza, nadużycie władztwa planistycznego może polegać na uzurpowaniu kompetencji planistycznych, co raczej w praktyce nie występuje, lub wadliwym odkodowaniu i realizowaniu norm planistycznych i zadaniowych w zakresie planowania i zagospodarowania przestrzennego (W. Jakimowicz, Władztwo..., s. 52). Z kolei A. Królczyk (Glosa do wyroku Naczelnego Sąu 
należytego wyważenia oznacza nieproporcjonalność, a w konsekwencji wadliwość władczej ingerencji w sferę praw jednostki.

Założeniem wyjściowym jest wspomniana wyżej względna samodzielność gminy w sferze planistycznej. Jak wskazał NSA w wyroku z 31 maja 2010 r. (II OSK 575/10):

\begin{abstract}
W kompetencji do uchwalania miejscowych planów zagospodarowania przestrzennego wyraża się samodzielność samorządu terytorialnego w rozwiązywaniu lokalnych zagadnień dotyczących zachowania ładu przestrzennego, gospodarki nieruchomościami, ochrony środowiska i przyrody oraz gospodarki wodnej, o których mowa w art. 7 ust. 1 pkt 1 ustawy o samorządzie gminnym [...]. Wyraźną wolą ustawodawcy było pozostawienie organom gminy uprawnienia do uchwalania planów zagospodarowania przestrzennego (aktów prawa miejscowego), przy jednoczesnym nałożeniu obowiązku przestrzegania reguł stanowienia prawa. Pamiętać przy tym należy, iż gmina wykonuje zadania publiczne w imieniu własnym i na własną odpowiedzialność, a jej samodzielność podlega ochronie sądowej. Granicą tej samodzielności jest sprzeczność z prawem [...]. Samodzielność gminy może być bowiem realizowana tylko w granicach dozwolonych prawem. [...] Wyłączna kompetencja gminy do planowania miejscowego wyraża się w samodzielnym kształtowaniu sposobu zagospodarowania obszaru podlegającego jej władztwu planistycznemu, pod warunkiem działania w granicach i na podstawie prawa i nie nadużywania tego władztwa ${ }^{48}$.
\end{abstract}

Zatem władztwo planistyczne nie jest i nie może być traktowane jako niczym nieograniczona ingerencja gminy w prawa właścicielskie. Ingerencja ta może się dokonywać wyłącznie na zasadzie poszanowania porządku prawnego i nie może prowadzić do nadużycia przysługujących gminie uprawnień ${ }^{49}$.

Kluczowymi elementami konstrukcji nadużycia władztwa planistycznego gminy jest nawiązanie do konstytucyjnych kryteriów dopuszczalności ingerencji w sferę prawną jednostek, w szczególności zasad proporcjonalności, ochrony własności i równości. Akty planistyczne gminy mogą niewątpliwie ingerować w sferę własności jednostek, kształtując sposób wykonywania tego prawa, muszą jednak stanowić wyraz właściwego wyważenia kolidujących dóbr i wartości, poprzez wykazanie, że przyjęte rozwiązania są optymalne - uzasadnione interesem

Administracyjnego z dnia 30.07.2010 r., sygn. akt II OSK 1053/10, Casus 2011, nr 1, s. 27), nawiązując do poglądów orzecznictwa, upatruje nadużycia władztwa planistycznego w nieuzasadnionej, naruszającej zasadę proporcjonalności, dowolnej i nieopartej na wszechstronnym wyważeniu interesu indywidualnego i publicznego ingerencji w prawa właścicielskiej.

48 Podobnie NSA w wyrokach z 5 lipca 2005 r. (OSK 1449/04, OSK 1453/04, OSK 1455/04, OSK 1456/04, OSK 1457/04), z 10 maja 2006 r. (II OSK 170/06), z 6 lipca 2007 r. (II OSK 604/07): „To, że gmina dysponuje zespołem uprawnień określanym władztwem planistycznym nie oznacza, że może to władztwo wykonywać dowolnie a jej samodzielność w tym zakresie jest nieograniczona. Mając kompetencje do planowania miejscowego gmina może pod warunkiem, że działa w granicach prawa i na podstawie prawa, samodzielnie kształtować sposób zagospodarowania obszaru podlegającego władztwu planistycznemu, jeżeli władztwa tego nie nadużywa a organy państwa w tym sądy administracyjne nie mogą jej władztwa planistycznego pozbawić”.

49 Wyroki NSA z 6 lipca 2007 r. (II OSK 604/07), z 18 października 2007 r. (II OSK 1191/07), z 8 listopada 2007 r. (II OSK 909/07). 
publicznym i nie ingerujące ponad niezbędną konieczność w sferę prawną jednostki. Niedopuszczalne jest również nieuzasadnione różnicowanie sytuacji adresatów rozstrzygnięć planistycznych gminy, godzące w zasadę równości wobec prawa.

Orzecznictwo obrazujące powyższy tok argumentacji jest bardzo bogate. Tylko tytułem przykładu można przytoczyć kilka fragmentów uzasadnień.

W cytowanym już wyroku z 22 listopada 2012 r. (II OSK 840/12) NSA wskazał:

Poza regulacjami ustawodawstwa zwykłego, organy gminy przy stanowieniu treści aktu planistycznego muszą uwzględniać również normy konstytucyjne statuujące m.in. zasadę równości czy proporcjonalności. [...] Gminy wprowadzając ograniczenia w korzystaniu z konstytucyjnie chronionego prawa własności, obowiązane są stosować takie środki prawne, które będą najmniej uciążliwe dla poszczególnych podmiotów oraz pozostaną w racjonalnej proporcji do zamierzonych celów. Nieuniknione jest jednak to, że przy tworzeniu miejscowego planu zagospodarowania przestrzennego ujawniają się sprzeczne interesy różnych podmiotów jak i kolizje interesów między poszczególnymi członkami wspólnoty samorządowej a samą wspólnotą. Niewątpliwie rozstrzyganie tych konfliktów w procesie stanowienia prawa wymaga każdorazowo wyważenia interesu poszczególnych właścicieli nieruchomości oraz interesu publicznego całej wspólnoty samorządowej. Zachowanie właściwej równowagi pomiędzy wartościami chronionymi konstytucyjnie i ustawowo wyklucza zakładanie prymatu interesu ogólnego nad jednostkowym i odwrotnie.

W kilku orzeczeniach wyrażono stanowisko, zgodnie z którym:

Brzmienie przepisów ustawy o planowaniu i zagospodarowaniu przestrzennym jednoznacznie wskazuje, że ,interes publiczny” nie uzyskał prymatu pierwszeństwa w odniesieniu do interesu jednostki. Rozwiązania prawne przyjęte w ustawie opierają się na zasadzie równowagi interesu ogólnopaństwowego, interesu gminy i interesu jednostki. Oznacza to obowiązek rozważnego wyważenia praw indywidualnych (interesów obywateli) i interesu publicznego, co ma szczególne znaczenie w przypadku kolizji tych interesów. [...] organy planistyczne winne mieć na uwadze, że kreowanie poprzez plan - na szczeblu gminy - polityki przestrzennej niejednokrotnie wymaga rozstrzygania konfliktów pomiędzy interesem indywidualnym a interesem gminy bądź pomiędzy sprzecznymi ze sobą interesami indywidualnymi. Plan zagospodarowania przestrzennego swoimi uregulowaniami niejednokrotnie wkracza bowiem w sferę praw rzeczowych właścicieli lub uprawnień innych podmiotów zainteresowanych przeznaczeniem terenu, ograniczając ich interesy. W trakcie rozwiązywania tych konfliktów uwzględniać należy zasady konstytucyjne w tym ustanowioną w art. 2 zasadę demokratycznego państwa prawa oraz wyrażoną w art. 31 ust. 3 Konstytucji zasadę proporcjonalności. W kontekście prawa własności zezwalają one na jego ograniczenie jedynie wówczas, gdy niezbędnie wymaga tego inne dobro chronione w postaci np. interesu publicznego lub prawa własności innych osób. W razie kolizji przyznanie prymatu jednemu interesowi nad innym, wymaga natomiast każdorazowo porównania wartości chronionych z tymi, które w efekcie wprowadzanej regulacji mają ulec ograniczeniu. W konsekwencji uczynienie jednego z interesów nadrzędnym, zwłaszcza, gdy chodzi o konflikt w pełni równorzędnych interesów jednostek, z których jedna doznać ma ograniczenia, wymaga szczególnej rozwagi i rzetelnego uzasadnienia ${ }^{50}$.

50 Por. wyrok WSA w Gliwicach z 16 lipca 2008 r., II SA/G1 178/08; wyrok WSA w Poznaniu z 25 kwietnia 2013 r., II SA/Po 985/12; wyrok WSA we Wrocławiu z 25 kwietnia 2013 r., II SA/Wr 134/13). Podobnie: wyroki NSA z 31 maja 2010 r. (II OSK 575/10), z 14 grudnia 2010 r. (II OSK 


\section{W wyroku z 21 sierpnia 2012 r. (II OSK 1339/12) NSA stwierdził:}

Ingerencja gminy w prawa właścicielskie. jest możliwa, ale musi też uwzględniać proporcjonalnie wyważony interes publiczny z uprawnieniami właścicielskimi. Wymaga to więc od gminy wnikliwego i wszechstronnego rozważenia interesu indywidualnego i publicznego oraz uzasadnienia prawidłowości przyjętych rozwiązań planistycznych, ich celowości i słuszności. Powyższe ma na celu wykluczenie zarzutu naruszenia przez gminę władztwa planistycznego poprzez jego nadużycie, co [...] stanowi o naruszeniu zasad sporządzania planu i stanowi podstawę do stwierdzenia nieważności jego części lub całości ${ }^{51}$.

W wyroku z 12 kwietnia 2012 r. (IV SA/Po 1021/11) WSA w Poznaniu zaakcentował, że ingerencja nawet w postaci zakazu zabudowy nie oznacza nadużycia władztwa planistycznego, jeżeli stanowi wynik rzetelnie przeprowadzonego rachunku aksjologicznego, uwzględniającego znaczenie dla interesu publicznego ochrony takich dóbr jak: walory widokowe, przyrodnicze oraz kulturowe i związane z ochroną zabytków.

W konkluzji można stwierdzić, że z bogactwa dorobku judykatury stosującej różne formuły argumentacyjne wyłania się podstawowa teza, w myśl której nieproporcjonalność władczej ingerencji wyrażająca się w braku właściwego wyważenia kolidujących wartości, które muszą być uwzględniane w planowaniu i zagospodarowaniu przestrzennym, oznacza nadużycie przez organy gminy przysługującego im z mocy ustawy władztwa planistycznego ${ }^{52}$.

Za nadużycie władztwa planistycznego gminy uznawano również naruszanie przez organy gminy zasady równości wobec prawa poprzez przyjmowanie

2073/10), z 27 października 2011 r. (II OSK 1679/11), z 12 września 2012 r. (II OSK 1271/12); wyrok WSA w Poznaniu z 25 kwietnia 2013 r. (II SA/Po 985/12); wyrok WSA w Warszawie z 16 lutego 2011 r. (IV SA/Wa 2084/10); wyrok WSA we Wrocławiu z 16 grudnia 2010 r. (II SA/Wr 446/10).

${ }^{51}$ Podobnie WSA w Gdańsku w wyroku z 29 kwietnia 2009 r. (II SA/Gd 563/08): „gmina kształtując sposób zagospodarowania obszaru podlegającego jej władztwu planistycznemu nie może tego władztwa nadużywać. Ograniczeniem dla uchwalanych planów miejscowych jest również potrzeba uwzględnienia sprzecznych interesów poszczególnych członków społeczności lokalnej bądź interesu indywidualnego z interesem publicznym. Wymaga to od gminy wnikliwego i wszechstronnego rozważenia interesu indywidualnego i publicznego, tak aby nie narazić się na zarzut dowolności i nadużycia władztwa planistycznego".

52 Por. m.in. wyroki NSA z 5 lipca 2005 r. (OSK 1449/04), z 16 listopada 2006 r. (II OSK 1425/05), z 8 stycznia 2010 r. (II OSK 1777/09), z 9 lutego 2010 r. (II OSK 1959/09), z 30.3.2011 r. (II OSK 13/11), z 9 listopada 2011 r. (II OSK 1725/11), z 25 września 2012 r. (II OSK 1377/12), z 23 stycznia 2013 r. (II OSK 2348/12); wyroki WSA w Białymstoku z 21 listopada 2006 r. (II SA/ Bk 46/06), z 9 lutego .2009 r. (II SA/Bk 667/08); wyroki WSA w Gdańsku z 22 marca 2006 r. (II SA/ Gd 399/04), z 6 listopada 2012 r. (II SA/Gd 485/12); wyroki WSA w Krakowie z 15 lipca 2007 r. (II SA/Kr 128/07), z 11 marca 2011 r. (II SA/Kr 1461/10), z 4 lutego 2013 r. (II SA/Kr 1599/12); wyroki WSA w Lublinie z 19 listopada 2009 r. (II SA/Lu 454/09), z 28 maja 2013 r. (II SA/Lu 1020/12); wyroki WSA w Łodzi z 23 listopada 2005 (II SA/Łd 442,/05), z 17 lutego 2006 r. (II SA/ Łd 1184/05); wyroki WSA w Poznaniu z 18 lipca 2012 r. (II SA/Po 368/12), z 19 lutego 2013 r. (II SA/Po 810/12); wyroki WSA w Warszawie z 21 marca 2012 r. (IV SA/Wa 33/12), z 16 kwietnia 2013 r. (IV SA/Wa 573/13); wyrok WSA we Wrocławiu z 16 listopada 2009 r. (II SA/Wr 143/09). 
rozwiązań różnicujących sytuację prawną właścicieli nieruchomości objętych planem, nadmierne obciążanie jednych kosztem drugich, przyjmowanie różnych rozwiązań bez jakiejkolwiek zasadnej argumentacji w odniesieniu do właścicieli znajdujących się w takiej samej sytuacji ${ }^{53}$. Odwoływano się także do zasady sprawiedliwości społecznej, wskazując, że władztwo planistyczne nie powinno w sposób nadmierny, z pogwałceniem zasady sprawiedliwości społecznej, naruszać interesów prawnych jednych, chroniąc innych ${ }^{54}$.

Konieczność wyważenia kolidujących wartości oznacza, że skarżący nie może skutecznie podnosić zarzutu nadużycia władztwa planistycznego gminy tylko na tej podstawie, że przyjęte rozwiązania planistyczne są niezgodne z jego interesem: „Nie można utożsamiać nadużycia władztwa planistycznego z uregulowaniem w planie zasad przeznaczenia terenu w sposób, który nie odpowiada skarżącemu” ${ }^{\text {". }}$, Koncepcja władztwa planistycznego zakłada nie tylko samodzielność gminy, ale i możliwość ingerencji w prawa prywatne (w granicach określonych prawem). Oznacza zatem, że zainteresowane podmioty (w tym właściciele nieruchomości położonych w granicach planu) nie mogą oczekiwać, że rada gminy nie będzie korzystała z przysługujących jej uprawnień w ramach władztwa z powodu niezgodności ustaleń planu z żądaniami właścicieli nieruchomości znajdujących się na obszarze objętym planem lub w bezpośrednim sąsiedztwie"56.

Zróżnicowany charakter wartości, które muszą być uwzględniane w planowaniu i zagospodarowaniu przestrzennym (art. 1 ust. 2 u.p.z.p.) sprawia, że nie zawsze jest możliwe ich uwzględnienie w maksymalnym zakresie według żądań zainteresowanych podmiotów, gdyż niejednokrotnie dochodzi do kolizji tych wartości. W tej sytuacji prawo własności musi być często ograniczone ze wzglę-

${ }_{53}$ Por. wyrok NSA z 31 stycznia 2013 r. (II OSK 2391/12); wyrok WSA w Gorzowie Wlkp. Z 2 marca 2011 r. (II SA/Go 16/11). Podobnie: wyrok NSA z 15 stycznia 2013 r. (II OSK 1976/12); wyrok WSA w Białymstoku z 22 marca 2013 r. (II SA/Bk 36/13); wyrok WSA w Gdańsku z 29 kwietnia 2009 r. (II SA/Gd 563/08); wyrok WSA w Krakowie z 5 listopada 2009 r. (II SA/Kr 1388/09); wyrok WSA w Poznaniu z 30 listopada 2012 r. (II SA/Po 548/12); wyrok WSA w Warszawie z 17 marca 2011 r. (IV SA/Wa 178/11); wyrok WSA we Wrocławiu z 25 kwietnia 2013 r. (II SA/Wr 134/13).

54 Por. wyrok NSA z 1 grudnia 1999 r. (IV SA 1387/99, LEX nr 48258); wyrok WSA w Bydgoszczy z 16 listopada 2004 r. (II SA/Bd 774/04); wyrok WSA w Warszawie z 16 lipca 2009 r. (IV SA/Wa 539/09).

55 Wyrok WSA w Bydgoszczy z 17 lutego 2009 r. (II SA/Bd 1011/07). Podobnie: „Podjęcie uchwały mimo sprzeciwu części właścicieli nieruchomości znajdujących się w obszarze planu lub w pobliżu planowanych rozwiązań planistycznych, mogących negatywnie oddziaływać na sferę prawną tych podmiotów nie jest nadużyciem władztwa planistycznego" (wyroki WSA w Lublinie z 11 kwietnia 2006 r., II SA/Lu 215/06 oraz z 4 października 2007 r., II SA/Lu 267/07).

56 Por. wyrok NSA z dnia 26 lutego 2008 r. (II OSK 1765/07); wyrok WSA w Białymstoku z 18 czerwca 2013 r. (II SA/Bk 964/12); wyrok WSA w Lublinie z 2 października 2008 r. (II SA/Lu 342/08). Podobnie NSA w wyroku z 4 listopada 2010 r. (II OSK 1804/10): „Przyjęcie, że gmina nie może wyłączyć pewnych gruntów spod zabudowy, kierując się interesem społecznym, gdyż sprzeciwiają się temu ich właściciele, podważałoby istotę przysługującego gminie władztwa planistycznego". 
du na konieczność uwzględnienia innych wartości, jak potrzeby interesu publicznego, potrzeby bezpieczeństwa czy obronności, wymagania ochrony środowiska czy ochrony dóbr kultury. Nie oznacza to dowolności powodującej przekroczenie granic władztwa planistycznego gminy. Działając w ramach określonych przez granice prawa i stosując zasadę proporcjonalności organy gminy mogą $\mathrm{w}$ tworzonym planie zagospodarowania przestrzennego ograniczać uprawnienia właścicieli w celu pełniejszej realizacji innych wartości, które uznały za ważniejsze ${ }^{57}$.

Orzecznictwo konstytucyjne i literatura wskazują na trzy składowe elementy zasady proporcjonalności ingerencji - przydatność, konieczność (niezbędność) i proporcjonalność w sensie ścisłym. Przydatność nakazuje wybór środków pozwalających na skuteczną realizację celu. Z konieczności płynie nakaz, aby spośród środków równie skutecznych wybrać ten, który jest najmniej uciążliwy dla jednostki. Wreszcie proporcjonalność w sensie ścisłym nakazuje aby zastosowane środki pozostawały $\mathrm{w}$ proporcji do założonego celu $^{58}$. Nawiązanie do tych poglądów widać w orzecznictwie sądów administracyjnych akcentujących racjonalność i optymalność przyjętych rozwiązań planistycznych ingerujących w sferę chronionych dóbr i wolności jednostki.

W wyroku z 19 czerwca 2006 r. (II OSK 1404/05) NSA podkreślił, że władztwo planistyczne powinno być wykonywane racjonalnie, wybierając optymalne w danej sytuacji rozwiązania i respektując uzasadnione interesy prawne obywate$1 i^{59}$. W licznych orzeczeniach wskazywano, że wynikająca z władztwa planistycznego gminy swoboda decydowania o przeznaczeniu i zagospodarowaniu terenu, nie zaprzecza jednocześnie konieczności uwzględniania racjonalności w działaniu gminy w tym zakresie, realizującej się w przyjmowaniu finalnych, optymalnych rozwiązań planistycznych ${ }^{60}$. Z kolei w wyroku z 9 lutego 2010 r. (II OSK 1959/09) NSA nawiązując do wymogu konieczności ingerencji wskazał, że ograniczenie właścicieli w ich prawie własności, czego można spodziewać się po miejscowym

57 Wyrok NSA z 16 czerwca 2011 r. (II OSK 595/11). W podobnym kierunku: „Wprowadzone ograniczenia są rezultatem uwzględnienia wymogów interesu publicznego i choć w sposób znaczący utrudniają skarżącej wykonywanie prawa własności to jednak nie wiążą się z nadużyciem władztwa planistycznego gminy" (wyrok NSA z 15 lutego 2010 r., II OSK 1920/09).

58 Por. wyrok TK z 11 maja 1999 r., K. 13/98; OTK 1999, nr 4, poz. 74; K. Wojtyczek, Granice ingerencji ustawodawczej w sferę praw człowieka w Konstytucji RP, Kraków 1999, s. 139 i n. oraz tenże, Zasada proporcjonalności, [w:] B. Banaszak, A. Preisner (red.), Prawa i wolności obywatelskie w Konstytucji RP Warszawa 2002, s. 670 i 682). Podobnie M. Wyrzykowski, Granice praw i wolności-granice władzy, [w:] Obywatel-jego wolności i prawa. Zbiór studiów przygotowanych z okazji 10. lecia urzędu Rzecznika Praw Obywatelskich, Warszawa 1998, s. 51.

${ }_{59}$ Podobnie NSA w wyroku z 12 kwietnia 2001 r. (IV SA 2449/00). W wyroku z 12 września 2012 r. (II OSK 1422/12) NSA podkreślił, że „każde wyznaczenie w miejscowym planie zagospodarowania przestrzennego ograniczeń w wykonywaniu prawa własności musi być adekwatne do potrzeb interesu publicznego, dla osiągnięcia których ograniczenia te zostały wprowadzone.

${ }^{60}$ Por. wyrok WSA w Poznaniu z 12 kwietnia 2012 r. (IV SA/Po 1021/11); wyrok WSA w Warszawie z 10 listopada 2011 r. (IV SA/Wa 1227/11); wyroki WSA we Wrocławiu z 21 lipca 2005 r. (II SA/Wr 649/03), z 1 sierpnia 2008 r. (II SA/Wr 403/06), z 12 maja 2010 r. (II SA/Wr 144/10). 
planie zagospodarowania, uzasadnia tylko cel publiczny, ale także tylko wówczas, gdy innego rozwiązania, choć go szukano, nie można było znaleźć. Nieprzestrzeganie tej reguły może prowadzić do nadużycia władztwa planistycznego.

W związku z powyższym orzecznictwo wskazuje, że nie można stawiać organom gminy zarzutu nadużycia władztwa, gdy przyjęte rozwiązania są racjonalne i optymalne w danych okolicznościach ${ }^{61}$, lub na odwrót - brak rozważenia wszystkich dostępnych wariantów rozwiązania planistycznego pod kątem wyboru najlepszego $\mathrm{z}$ nich, tzn. pozwalającego $\mathrm{w}$ pełni zaspokoić interes publiczny i w jak najmniejszym stopniu ograniczającym własność jednostek jest uznawane za nadużycie władztwa planistycznego ${ }^{62}$.

Stosowanie kryteriów racjonalności i optymalności rozwiązań planistycznych nie oznacza sięgania przez sąd do kryterium celowości zaskarżonego aktu, są to elementy oceny proporcjonalności ingerencji, pozostające w sferze badania legalności zaskarżonego aktu, z punktu widzenia zasad konstytucyjnych.

W licznych orzeczeniach sądy podkreślają rolę należytego uzasadnienia aktów planistycznych - wykazującego zachowanie właściwych proporcji i rozważenia wszystkich kolidujących racji. Brak należytego uzasadnienia wprowadzanych w planie miejscowym ograniczeń jest traktowany jako nadużycie władztwa planistycznego gminy ${ }^{63}$.

${ }^{61}$ Por. wyrok NSA z 14 grudnia 1998 r. (IV SA 743/98, LEX nr 43700): „W ocenie Sądu w niniejszej sprawie do takiego nadużycia władztwa nie doszło, o czym świadczy w szczególności uzasadnienie dla przyjętego wariantu projektowanej trasy komunikacyjnej jako «najkrótszego z możliwych i prawidłowego pod względem funkcjonalnym i technicznym»"; wyrok WSA w Warszawie z 28 grudnia 2008 r. (IV SA/Wa 891/07): „Dopuszczenie możliwości realizacji zabudowy małogabarytowej, budynków trzykondygnacyjnych oraz budynków usługowych jest zdaniem Sądu rozwiązaniem racjonalnym i nie stanowi nadużycia władztwa planistycznego". Podobnie m.in.: wyrok WSA w Gdańsku z 7 kwietnia 2011 r. (II SA/Gd 872/10); wyrok WSA w Krakowie z 8 września 2009 r. (II SA/Kr 1062/08); wyroki WSA w Poznaniu z 13 maja 2009 r. (IV SA/Po 156/09), z 8 maja 2013 r. (IV SA/Po 507/12).

${ }^{62}$ „Uzasadnienie uchwały przekonywać winno, że przyjęte w projekcie planu rozwiązanie jest konieczne i nie wprowadza ingerencji w prawo własności ponad bezwzględną potrzebę. Przy wielu natomiast wariantach rozwiązań wykazywać zaś musi, iż zaproponowane w projekcie planu jest najlepsze" (wyrok WSA w Warszawie z 5 marca 2004 r. IV SA 4677/03). ,zaprojektowanie w planie miejscowym drogi publicznej w ten sposób, że linia rozgraniczająca tę drogę przebiega przez budynek jest dopuszczalne tylko wtedy, gdy zostanie wykazane przez gminę, że nie było innego, mniej uciążliwego wariantu przebiegu drogi. Ze znajdujących się w aktach dokumentów zdaje się zaś wynikać, że drogę tę można by poprowadzić przez tereny niezabudowane. Bez wyjaśnienia tej kwestii postępowanie organów gminy, mające swój wyraz w poprowadzeniu drogi przez budynek, może być uznane za nadużycie władztwa planistycznego (Wyrok NSA z 5 czerwca 2012 r., II OSK 706/12). Podobnie m.in.: wyroki WSA w Gdańsku z 29 kwietnia 2009 r. (II SA/Gd 563/08) i z 14 listopada 2012 r. (II SA/Gd 257/12); wyroki WSA w Poznaniu z 20 sierpnia 2010 r. (II SA/Po 184/10), i z 12 lutego 2013 r. (II SA/Po 1029/12); wyroki WSA w Warszawie z 16 lipca 2009 r. (IV SA/Wa 539/09), z 16 lutego 2011 r. (IV SA/Wa 2084/10).

${ }^{63}$ Por. wyrok NSA z 23 listopada 1998 r. (IV SA 617/98, LEX nr 43722); wyrok WSA w Gdańsku z 14 listopada 2012 r. (II SA/Gd 257/12); wyrok WSA w Poznaniu z 31 maja 2006 r. (II SA/Po 209/06). 
Sądy wskazują, że ingerencja gminy poprzez działania planistyczne w sferę prawną podmiotu, naruszająca atrybuty właścicielskie, dla swej legalności wymaga bezwzględnie wykazania, że gmina stanowiąc w planie miejscowym o przeznaczeniu terenu i sposobie jego zagospodarowania nie nadużyła władztwa planistycznego. Powinno to nastąpić w uzasadnieniu uchwały w sprawie planu, wyjaśniającym przesłanki, którymi gmina kierowała się przyjmując konkretne rozwiązania planistyczne, wpływające na sposób wykonywania prawa własności przez dysponenta prawa. Uzasadnienie uchwały winno zawierać argumentację pozwalającą uznać, że gmina dołożyła należytej staranności w przestrzeganiu zasad obowiązujących przy podejmowaniu działań planistycznych, w tym rozważyła inne warianty zrealizowania zamierzenia planistycznego $\mathrm{w}$ ramach przyjętej koncepcji, albo że przyjęte rozwiązanie planistyczne, mimo konieczności dokonania ingerencji w sferę prawa własności, jest jedynym możliwym w danych warunkach $^{64}$. Brak uzasadnienia uchwały w sprawie planu miejscowego w zakresie w jakim wprowadza istotne ograniczenia prawa własności uniemożliwia nie tylko organowi nadzoru zbadanie zgodności jej postanowień z prawem ale także właścicielom nieruchomości objętych planem utrudnia ocenę racjonalności i zasadności wprowadzonych rozwiązań prawnych, zwłaszcza w sytuacji gdy ograniczają one w poważnym zakresie korzystanie z własności nieruchomości ${ }^{65}$.

W orzecznictwie wskazuje się również na związek obowiązku uzasadniania aktów planistycznych z zasadami ochrony zaufania jednostki, jawności działań władzy publicznej i funkcjami sądowej kontroli administracji publicznej.

Działanie organu władzy publicznej, mieszczące się w jego prawem określonych kompetencjach, ale noszące znamiona arbitralności i niepoddające się kontroli i nadzorowi, nie może być bowiem uznane za zgodne z prawem. Obowiązek działania na podstawie prawa, w połączeniu z zasadą zaufania, stwarza po stronie organów władzy publicznej obowiązek rzetelnego uzasadniania jej rozstrzygnięć. Obowiązek taki jest zaliczany do standardów demokratycznego państwa prawnego. Obowiązek uzasadniania uchwał rady gminy jest też elementem zasady jawności działania władzy publicznej. Prawny obowiązek sporządzenia uzasadnienia uchwały przez organ stanowiący jednostki samorządu terytorialnego wynika także z konstytucyjnej funkcji sądownictwa administracyjnego. [...] Organ jednostki samorządu terytorialnego podejmujący uchwałę ma obowiązek sporządzenia uzasadnienia uchwały, gdyż takie uzasadnienie warunkuje kontrolę sprawowaną przez sąd administracyjny ${ }^{66}$.

${ }^{64}$ Por. m.in. wyroki NSA z 19 czerwca 2006 r. (II OSK 1404/05), z 1 grudnia 2009 r. (II OSK 1431/09), z 1 grudnia 2010 r. (II OSK 1922/10), z 22 czerwca 2012 r. (II OSK 878/12); wyrok WSA w Gdańsku z 12 października 2011 r. (II SA/Gd 265/11); wyrok WSA w Krakowie z 31 maja 2011 r. (II SA/Kr 85/11); wyrok WSA w Poznaniu z 25 kwietnia 2013 r. (II SA/Po 985/12).

65 Wyrok NSA z 1 grudnia 2009 r. (II OSK 1431/09).

${ }^{66}$ Por. wyrok NSA z 8 czerwca 2009 r. (II OSK 1468/08); wyrok WSA w Białymstoku z 13 kwietnia 2006 r. (II SA/Bk 83/06); wyroki WSA w Poznaniu z 19 stycznia 2012 r. (II SA/Po 564/11), z 19 lutego 2013 r. (II SA/Po 810/12). 
Tylko wówczas można bowiem ocenić, czy przy uchwalaniu planu nie doszło do przekroczenia przysługującego gminie władztwa planistycznego i czy dostatecznie zostały wyważone interesy jednostek i interes publiczny ${ }^{67}$.

\section{Podsumowanie}

Specyfika działalności administracji publicznej, której główną dyrektywą kierunkową jest realizacja interesu publicznego z jednej strony, oraz podstawowy czynnik wyznaczający granice tej działalności, czyli konieczność respektowania zagwarantowanych prawem wolności jednostki z natury rzeczy staje się źródłem polaryzacji interesów. Kolizja dóbr i wartości chronionych jest zatem zjawiskiem permanentnym i rolą administracji (a także sądów kontrolujących jej działalność) musi być stałe ważenie tych dóbr i wartości. Doskonale ukazuje to sfera planowania przestrzennego, z racji swej wręcz ,naturalnej” konfliktogenności. Podstawowym czynnikiem determinującym korzystanie $\mathrm{z}$ władztwa planistycznego jest dążenie do optymalnego wyważenia wartości interesu publicznego, wyrażającego się w takim zarządzaniu przestrzenią, aby zapewnić jej optymalne, zrównoważone wykorzystanie, oraz interesu indywidualnego, wymagającego ochrony własności, stanowiącej materialny fundament wolności jednostki. Koncepcja nadużycia władztwa planistycznego, wychodząc od uznania ograniczonej samodzielności gminy planowania i zagospodarowania przestrzennego, akcentuje, że niezależnie od wymogów zachowania właściwej procedury władztwo to ograniczają także fundamentalne, umocowane konstytucyjnie bariery władczej ingerencji w sferę praw jednostki. Nieproporcjonalność władczej ingerencji wyrażająca się w braku właściwego wyważenia kolidujących wartości, które muszą być uwzględniane w planowaniu i zagospodarowaniu przestrzennym, stanowi nadużycie przez organy gminy przysługującego im z mocy ustawy władztwa planistycznego.

${ }^{67}$ Wyrok WSA w Lublinie z 10 czerwca 2010 r. (II SA/Lu 86/10). Podobnie WSA w Warszawie w wyroku z 25 stycznia 2005 r. (IV SA/Wa 294/04). 